\title{
JOURNALS ANALYSIS IN UROLOGY AND PLASTIC SURGERY
}

Análise dos periódicos da urologia e cirurgia plástica

Alberto Azoubel Antunes

\section{A B STRACT}

Objective: Find out the main journals used in Urology and Plastic Surgery. Methods: Was consulted the WebQualis database and selected the "consult" after the "rating" and finally by "journal title." Also was crossed the following keywords: urology, urologic, urological, prostate, prostatic, plastic, reconstructive, aesthetic. The journals classified in the field of Capes Medicine III were selected, and registered their respective strata. To confirm the 2014 impact factor, was consulted the http://www.impactfactorsearch.com/ database; simply typing the journal title its impact factor appears automatically. Results: Was found 23 journals in Urology and 12 in Plastic Surgery. The average impact factor of urological journals was 2,256 and in Plastic Surgery 1,060. Among the urological journals, seven (30.4\%) were in the A WebQualis rating and among Plastic Surgery only one (8.3\%) was found in this stratum. Conclusion: There are quantitative and qualitative differences between journals in Urology and Plastic Surgery. These data can help to develop appropriate assessment methods for each specialty, considering the different features of the presented papers.

Key Words - Postgraduate education. Educational evaluation. Higher education. Health research evaluation. Program evaluation and research instruments. Staff development

\section{INTRODUCTION}

T: he Qualis system is defined by the Higher Education Personnel Improvement Coordination (Capes) as a list of vehicles used for the dissemination of the intellectual production of stricto sensu postgraduate programs ${ }^{1}$. Currently represents the main measure of quality of postgraduate product.

However, when different areas of knowledge are compared, the different journals profiles found difficulties in establishing uniform evaluation criteria. Thus, it is extremely important knowledge of both culture and publishing habits of each area, as well as the quality of the journals in each specialty.

The aim of this analysis was to underline the main journals used in Urology and Plastic Surgery.

\section{METHODS}

To identify the most used journals by urologists and plastic surgeons was consulted the WebQualis database ${ }^{2}$. Was select the option "consult" after the "rating" and finally by "journal title." From this point were used some keywords to identify the journals: urology, urologic, urological, prostate, prostatic, plastic, reconstructive, aesthetic. The journals classified in the Medicine III Capes area were selected, and their respective strata were recorded.

For confirmation of the 2014 impact factor (IF), was consulted the database http://www.impactfactorsearch.com/3 typing the journal name and automatically revealing its IF.

\section{RESULTS}

Were found 23 journals in Urology and 12 in Plastic Surgery. The average impact factor of urological journals was 2,256 and in Plastic Surgery 1,060. Among the urological journals, seven (30.4\%) were in the A WebQualis rating and among Plastic Surgery only one (8.3\%) was found in this stratum. (Figures 1 e 2).

Table 1 describes the Urology journals with their respective strata and IF, and Table 2 the journals in Plastic Surgery.

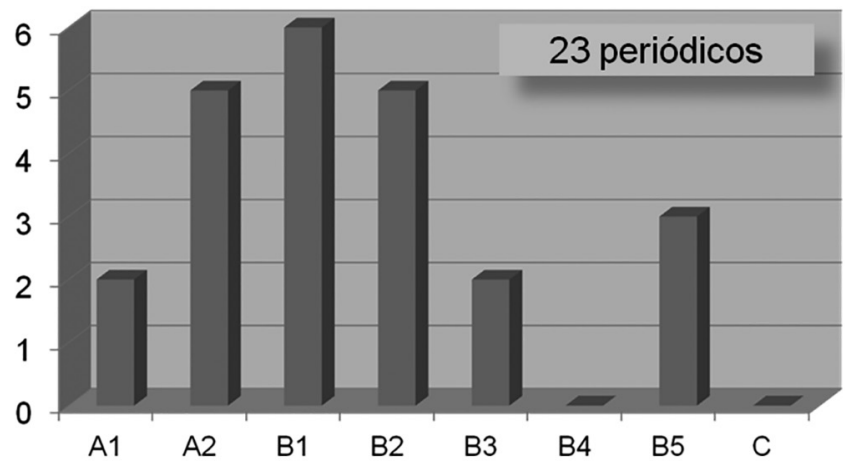

FIGURE 1 - Qualis Urology journals distribution according to the strata of the Qualis system

TABLE 1 - Main journals in Urology with their respective strata and IF (ISI 2014)

\begin{tabular}{|l|l|l|l|}
\hline ISSN & Title & Strata & IF \\
\hline $0302-2838$ & European Urology & A1 & 12.480 \\
\hline $1759-4812$ & Nature Reviews Urology & A1 & 4.522 \\
\hline $1471-2490$ & BMC Urology (Online) & A2 & 1.937 \\
\hline $0963-0643$ & Current Opinion in Urology & A2 & 2.115 \\
\hline $0733-2467$ & Neurourology and Urodynamics & A2 & 2.458 \\
\hline $0022-5347$ & The Journal of Urology & A2 & 3.753 \\
\hline $0270-4137$ & The Prostate & A2 & 3.566 \\
\hline $1569-9056$ & European Urology Supplement & B1 & 3.370 \\
\hline $1442-2042$ & International Journal of Urology & B1 & 1.798 \\
\hline $0892-7790$ & Journal of Endourology & B1 & 2.095 \\
\hline $0090-4295$ & Urology & B1 & 2.132 \\
\hline $0724-4983$ & World Journal of Urology & B1 & 3.423 \\
\hline $0365-7852$ & Prostate cancer \& prostatic diseases & B1 & 2.830 \\
\hline $1687-6369$ & Advances in Urology (Print) & B2 & - \\
\hline $1677-5538$ & International Brazilian Journal of Urology & B2 & 0.956 \\
\hline $0301-1623$ & International Urology and Nephrology & B2 & 1.293 \\
\hline $1477-5131$ & Journal of Pediatric Urology & B2 & 1.413 \\
\hline $0036-5599$ & Scandinavian Joumal of Urology and Nephrology & B2 & 1.062 \\
\hline $0970-1591$ & Indian Journal of Urology & B3 & - \\
\hline $1735-1308$ & Urology Journal & B3 & 0.707 \\
\hline $2168-9857$ & Medical \& Surgical Urology & B5 & - \\
\hline $1542-8745$ & The American Journal of Urology Review & B5 & - \\
\hline $1352-9544$ & Urology International & B5 & - \\
\hline
\end{tabular}




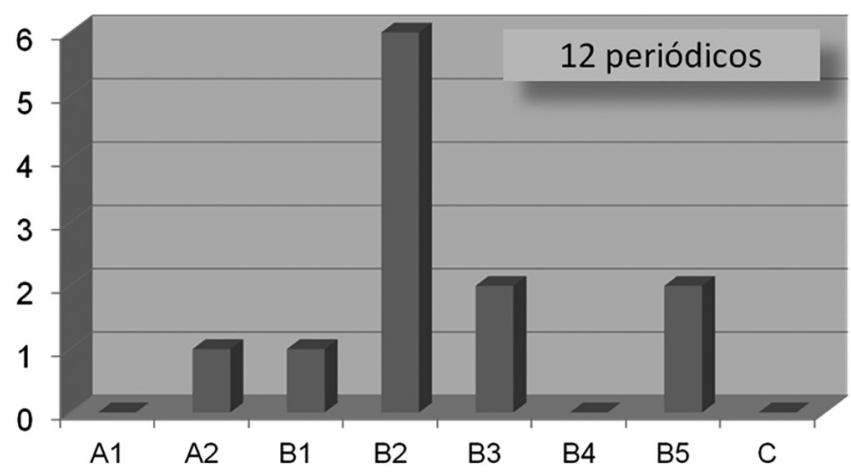

FIGURE 2 - Plastic Surgery journals distribution according to the strata of the Qualis system

TABLE 2 - Main journals in Plastic Surgery with their respective strata and IF (ISI 2014)

\begin{tabular}{|l|l|l|l|}
\hline ISSN & Title & Strata & IF \\
\hline $0032-1052$ & Plastic and Reconstructive Surgery & A2 & 3.328 \\
\hline $1521-2491$ & Archives of Facial Plastic Surgery & B1 & 1.623 \\
\hline $0364-216$ X & Aesthetic Plastic Surgery & B2 & 1.189 \\
\hline $0148-7043$ & Annals of Plastic Surgery & B2 & 1.458 \\
\hline $0094-1298$ & Clinics in Plastic Surgery & B2 & 1.350 \\
\hline $1748-6815$ & $\begin{array}{l}\text { Journal of Plastic, Reconstructive \& } \\
\text { Aesthetic Surgery }\end{array}$ & B2 & 1.474 \\
\hline $0284-4311$ & $\begin{array}{l}\text { Scand Journal of Plastic and Recon- } \\
\text { structive Surg and Hand Surg }\end{array}$ & B2 & - \\
\hline $1090-820 X$ & Aesthetic Surgery Journal & B2 & 2.034 \\
\hline $1195-2199$ & Canadian Journal of Plastic Surgery & B3 & 0.274 \\
\hline $0930-343 X$ & European Journal of Plastic Surgery & B3 & - \\
\hline $2090-1461$ & Plastic Surgery International & B5 & - \\
\hline $2164-7593$ & Plastic Surgery Pulse News & B5 & - \\
\hline
\end{tabular}

\section{DISCUSSION}

Knowledge of journals in each specialty is of fundamental importance for the development of reliable and accurate evaluation methods. This survey revealed that Urology has superiority to Plastic Surgery with regard to the quantity and quality of the periodic reviews. This fact becomes clear when we note that while only one journal in Plastic Surgery was classified in stratum Qualis A, seven in Urology are in this stratum. This fact complicates the assessment of researchers working in the field of Urology and Plastic Surgery by the same criteria.

The limitations of this analysis is that we highlight the fact that there are a lot of interface among medical specialties, enabling urologists to publish in journals of Nephrology (eg articles on kidney transplant), geriatrics, oncology, and even Plastic Surgery, and they are not counted in this survey. Likewise, plastic surgeons can publish in Head and Neck Surgery journals, Neurosurgery, or in surgical and reconstructions specialties involving mutilating operations.

We cannot forget the journals of general medicine, which can be the focus of any specialty that addresses issues of great medical interest. In general these journals have IF much higher because they have greater penetration in the general medical community and are read and cited by more doctors and researchers. New England Journal of Medicine, JAMA, Nature, Science, etc. are highlighted

\section{CONCLUSION}

There are quantitative and qualitative differences between urologic and Plastic Surgery journals. This data can help to develop evaluation methods suitable for each specialty, considering the different characteristics of the presented jounals.

\section{RESUMO}

Objetivo: Procurar destacar os principais periódicos utilizados na urologia e na cirurgia plástica. Métodos: Foi consultada a base de dados WebQualis. Selecionou-se a opção "consultar", depois a opção "classificação" e por fim por "título do periódico". Cruzaram-se também os seguintes descritores: urology, urologic, urological, prostate, prostatic, plastic, reconstructive, aesthetic. Os periódicos classificados na área da Medicina III da Capes foram selecionados, e seus respectivos estratos registrados. Para confirmação do fator de impacto de 2014, consultou-se a base de dados http://www.impactfactorsearch.com/, onde a digitação do nome do periódico revela automaticamente seu impacto. Resultados: Foram encontrados 23 periódicos urológicos e 12 na cirurgia plástica. O fator de impacto médio dos urológicos foi de 2.256 e o da cirurgia plástica de 1.060. Entre os periódicos urológicos, sete (30,4\%) encontravam-se no estrato A do Qualis e entre os da cirurgia plástica apenas um (8,3\%) encontrava-se neste estrato. Conclusão: Existem diferenças quantitativas e qualitativas entre os periódicos urológicos e os da cirurgia plástica. Estes dados podem auxiliar na elaboração de métodos de avaliação adequados para cada especialidade, considerando-se as diferentes características dos periódicos apresentados.

Descritores - Educação de pós-graduação. Avaliação educacional. Educação superior. Avaliação da pesquisa em saúde. Avaliação de programas e instrumentos de pesquisa. Desenvolvimento de pessoal

\section{REFERENCES}

1. O novo Qualis, ou a tragédia anunciada. Rocha-e-Silva, M; Clinics (São Paulo) 2009; 64(1): 1 -4.

2. http://qualis.capes.gov.br/webqualis. Acesso em dezembro de 2014

3. http://www.impactfactorsearch.com/ Acesso em dezembro de 2014.
Received on: 19/02/2015

Accepted for publication: 12/09/2015

Conflict of interest: none

Source of funding:

Address for correspondence:

Alberto Azoubel Antunes

antunesuro@uol.com.br 